\title{
Infusing Skills Acquisition Contents In Reading Comprehension Via Information And Communication Technologies (Icts) For Economic Empowerment In Nigeria
}

\author{
Dr. D.N. Rinji \\ Department of arts and social science education \\ Faculty of education, university of Abuja, Abuja \\ Ohiare Udebu M.F. \\ Department of arts and social science education \\ Faculty of education, university of Abuja, Abuja
}

\begin{abstract}
The objective of this paper was to educate teachers of English Language at all levels of education in Nigeria, on how to make effective use of ICTs in teaching. Specifically, the paper has discussed briefly the introduction of Western Education in Nigeria with its flaws in the curriculum how Nigerians yearned for the type of education that would satisfy their desires. The paper advanced and discussed the introduction of Information and Communication Technologies in the global education system and in Nigeria in particular. Entrepreneurship and skills acquisition have also been discussed. Reading comprehension with its three levels of understanding have been discussed and how reading comprehension can be utilized in ICTs for the purpose of skills acquisition. In addition, the paper discussed how reading comprehension can be used to acquire skills of making some products. The importance of collaborative class work through the use of ICTs among school teachers has also been discussed. The paper discussed how project assignment can be given to students to work in pairs and groups to produce some products they have read about the processes of making them. In conclusion, the paper emphasized the importance of ICTs in schools and the use of reading comprehension in ICTs. It was recommended among others that teachers in English language class should integrate skill acquisition texts or passages through ICT in the reading comprehension class.
\end{abstract}

\section{INTRODUCTION}

Nigeria, like other countries of the world is aware of the importance of education. Hence, if the country invests heavenly in education, it is hoped to generate qualified and skilled manpower to develop its abundant natural resources. The introduction of western education in Nigeria during the colonial period from 1842 -1955 was a glimpse of the manifestation of the objective of education in the country. Since then, Nigerians have been yearning for the type of education for self-reliance. The first school in Nigeria was established in Badagry, Lagos by the Missionaries in 1946. On the establishment of the school, it was strongly recommended that the introduction of Agricultural Science Education should be embraced in the curriculum of the school. Faghulu as cited in Usuanlele states that the curriculum was intended to inculcate household economy, gardening and surveying and agricultural chemistry. That concept of curriculum was held on to by many commissions which were set by the colonial masters to review the curriculum for Nigeria educational system. However it was still done in Cavour of the colonial masters. Nwana (2012) confirms that the education system planted by the colonialists in Nigeria and by their religious partners (whether Christian or Islam) was designed to conform to the authoritative system of government which they introduced. 
The products of that system of education were clerks, catechists and labourers, the promoters of law-enforcement personnel, promoters of rote learning, manufacturing or craftsmen, promotion of competency in foreign languages and others. That kind of education was promoted against the system of education that would place Nigerians in a position of creativity and skills acquisition.

The concept of western education in Nigeria was far removed from the background needs of the people. There was therefore confusion among Nigerians on what type of education would best be suitable for the nation. Commissions were set after commissions to bring out the best type or education for Nigerians. Since Nigerians were then confused, one of he said decisions or a commission was rejected. It was therefore reported that:

In the twentieth century the Phelpstokes Commission of 1922 attempted to redirect the focus of education to work as it was generally felt that the education given to Africans was inadequate and inappropriate as it educated them away from their environment. The commission saw the need for education to keep the Africans in touch with the indigenous welfare of "they" tribes, to provide them with element of good agriculture and good hygiene and to give them training in good crafts and home economics. This type of education was highly resented by Africans themselves who preferred the type of education the white collar jobs gave them access to... (P.5)

The commission's recommendation was rejected because of the wrong preconceived objectives of education as planted in the mind of Africans. In his assertion, Usuanlele (2016) states that: "While moral and literacy education was aimed at pacification, practical subjects were aimed at improving services and meeting the needs of the colonial companies and their metropolitan industries". To support this assertion, Usuanlelc (2016) also cited Lord Lugard in the following words: "Not be used for growing yams, beans and in usual native fashion. School farms can best be used to instruct in the best methods of growing economic plants suitable to the district such as cocoa and para-rubber". Hence the type of Agriculture as introduced in the education system then was not in favour of Nigerians.

\section{The Quest for Scientific and Technological Development in Nigeria}

As time advanced, the education sector observed that the kind of education introduced by the colonial masters could not help in scientific and technological development. There was a need for a change of the national curriculum of education. In 1969, national Curriculum Conference was held in Lagos. It was meant to chart a new course in the nation's educational system. The hope was to empower Nigerians towards the path of scientific and technological development. Omolewa. (2007), but the idea was later thrown into a mire

Apart from the general concept of scientific and technological advancement desired by the nation, there was a new package designed for Junior Secondary School education. The 1969 National Conference recommended a three-year Junior Secondary School for the country. The curriculum was to impart in the students, knowledge in science, arts and technology. It was meant to reduce the rate or unemployment among Nigerian "youths by arming them with a sellable skill" (Ornolcwa, 2007). There was no meaningful-achievement made in that direction. Rather, there was more confusion in the system; that continued in the $60 \mathrm{~s}, 70 \mathrm{~s}, 80 \mathrm{~s}$ and even in the 90 s to date.

\section{Entrepreneurship Education in Nigeria}

The Nigeria education sector conceived entrepreneurship education for higher institutions of learning in the 80s. It was conceived on the premises of higher rate of unemployment among 
Rinji, D.N., \& Ohaire, U. M. F. (2017). Infusing Skills Acquisition Contents In Reading Comprehension Via Information And Communication Technologies (Icts) For Economic Empowerment In Nigeria. Advances in Social Sciences Research Journal, 4(5) 124-132

the university graduates. There was also an increase in the status of poverty among Nigerians, not because the nation lacked the resources, out because of artificial scarcity created by nefarious men. In his words, Bukola (2011) sates that:

However, political instability and inconsistencies in the socio-economic policies of successive government led to the emergence of high unemployment in Nigeria... It has been observed that tertiary education has not been properly included in the philosophy of self-reliance such as creating a new cultural and productive environment... (p. 2).

The conception of entrepreneurship in the curriculum of' higher education was to salvage this problem. Onundo (2011) views entrepreneurship education as a means of seeking "to provide students with the knowledge, skills and motivation to encourage entrepreneurial success in a variety of settings. Thus, a variety of entrepreneurship education should be offered at all levels of education, focusing on realization of different opportunities for self-employment. Stowe (2013) considers entrepreneurship education as a knowledge which is acquired for a purpose of setting up a business. Stowe (2013) states that entrepreneurship education is any educational activity or programme that promotes an understanding of how to start a business. This knowledge can be acquired through resources such as trade books, internet services, formal education as in entrepreneurship education and others. Entrepreneurship education is about skills acquisition and setting up a business.

\section{Skills Acquisition}

The concept of skill(s) acquisition IS acquiring and developing skills which can provide opportunities for one's survival when being graduated from school; and without government employment. Therefore, the school is the manufacturer of the society in that sense. Thus, to determine appropriate system for stabilization and improvement, the new social order should be that of industry, discipline, integrity, morality, creativity, sense of responsibility and selfreliance activities. These activities can be typing, using the computer, fixing cars, weaving and sewing, sculpting and knitting. Osimabale \& Bazza Lawal (2015). Skills acquisition may concern school learners and children out of school and some illiterate adult population of the society. Vocational and technical education can lead to the acquisition of these practical and applied skills as well as the scientific knowledge.

Vocational and technical skills prepare the individuals for industry, agriculture and commerce among others. They are usually provided at the Senior Secondary or lower tertiary institution level. Sheriff (2007) advocates that life-long acquired skills, when attained, prepare the individuals to be gainfully employed. This is achieved where teaching results in functional learning. According to Sheriff (2007), the objectives or the Universal Basic Education (UBE) Programme include the development or the entire citizenry. This helps to reduce incidents of school dropouts by means of improving relevance in quality and efficiency. Therefore, skills acquisition programme is synonymous to entrepreneurship education. Our school curriculum should have provision for these two programmes.

\section{Information and Communication Technologies and Skills Acquisition}

Changes in socio-economic and political realities in the world have led to constant innovations and education reforms. This agrees with Durkheims (1938) view that:

Educational transformations are always the result and symptoms of social transformation in terms of which they are to be explained. In order for people to feel at any particular moment in 
lime the need to change educational systems, it is necessary that new ideas and needs have emerged in which the former system is no longer adequate (p.167).

Education is therefore seen as an essential instrument in human life and for socio-economic transformations.

The quality, relevance and cost of secondary education are other various challenges faced by youth education in the world. It becomes imperative to think of innovative ways of knowledge creation, skills acquisition and know ledge sharing among the youth and adults in general. Information and communication technologies can be considered for expansion or access to education. The need may be to focus on the developmental challenges and their manifestations. Evoh (:2013) states that:

The effective use of technology to support education in Africa locates itself within the goals of socio-economic transformation, reconstruction and development of countries in the region...any investigation into the use of ICT as a tool for development of education in Africa covers three major contextual areas, two of which are educational and development issues (p.5).

Judging from the above quotation, ICTs are vital tools for skills acquisition and development. The major merits of ICTs integration in education include expansion of access to educational opportunities, increment of efficiency in educational management and enhancement of the quality of learning and teaching. Evoh (2013).

Figure 1: Potential of ICTs in Youth and Community Development

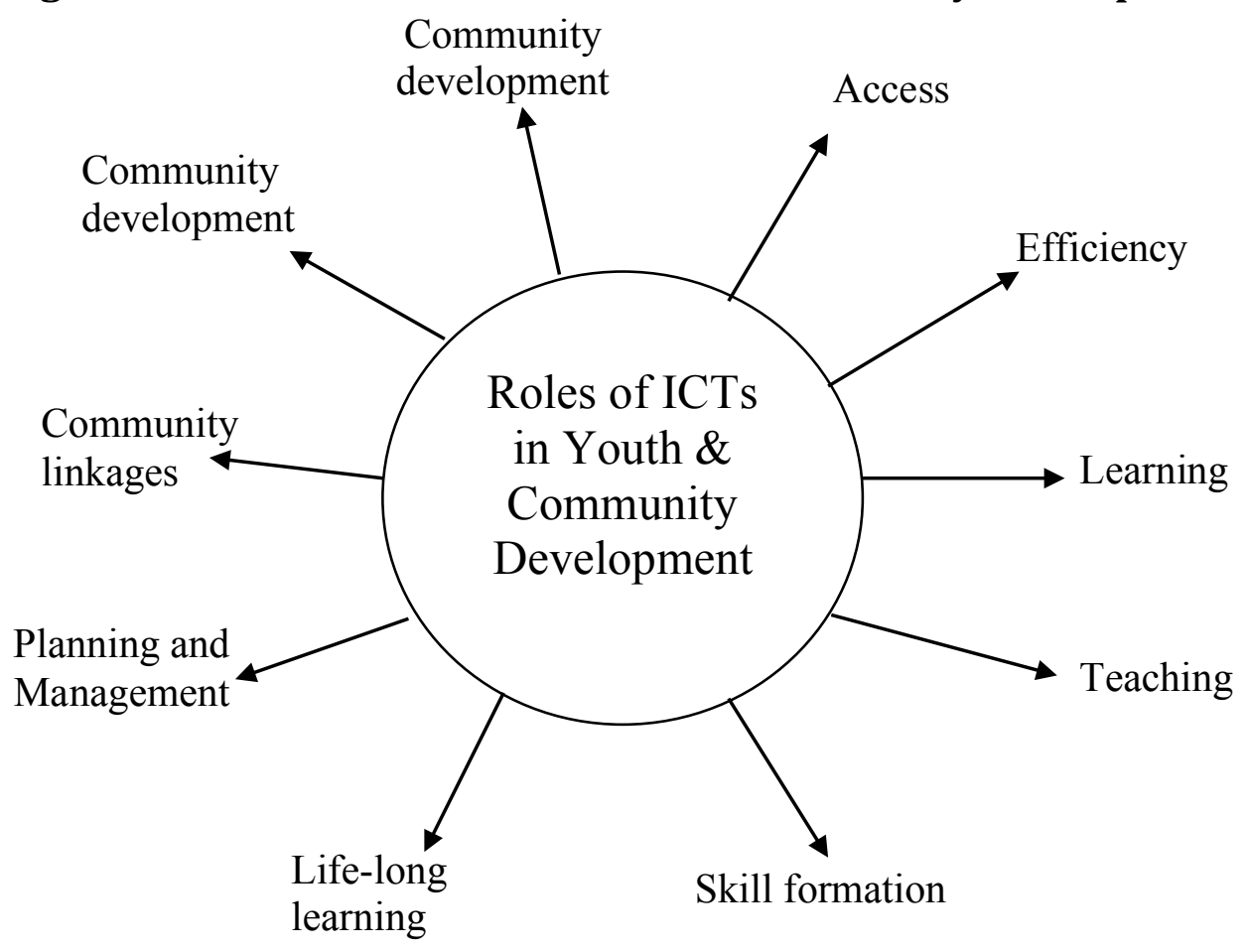

Adapted from Evoh 2013

The objective of ICTs in education shall be to provide a useful framework in which education pioneers, administrators and stakeholders in the education system can make effective and productive use of technologies in teaching-learning as well as administrative processes. 
Rinji, D.N., \& Ohaire, U. M. F. (2017). Infusing Skills Acquisition Contents In Reading Comprehension Via Information And Communication Technologies (Icts) For Economic Empowerment In Nigeria. Advances in Social Sciences Research Journal, 4(5) 124-132

It must be acknowledged that when w c plan and sustain ICT, in teaching and learning, it will transform educational conditions in Nigeria. This is because the economic potential of ICTs are numerous and are imperative to the development or individuals and the community. Hence Wilhelm (2003), Field and Hosman (2007) observe that:

Investment in ICTs for the poor in developing countries promises long term economic benefits in the overall social and economic development of these regions. Among such core benefits are improved cognition among learners, improvement in local small business entrepreneurship, teleeducation and tele-health capabilities, and empowering local farmers by bringing knowledge of market prices for crops (p.8).

ICTs are tools to an end not ends to themselves when referred to skills acquisition. This is because technology is the "manifestation of human creativity channeled towards problem solving, Lewis (1999). It is obvious that the rate of returns to the development depends on information and communication technologies for educational and vocational training. This can also be understood within the context of the level of technology adoption in social and economic activities of the people. (Knowles \& Behrman, 2006).

The use of ICTs in schools is for the purpose of' skills acquisition of the young learners. The knowledge of ICTs can make them to find innovative ways of educating and improving the labour force. ICTs can also help to improve the livelihood of the youths and communities by expanding educational opportunities, training and a better income prospect. Reading comprehension in ICTs therefore becomes the main instrument. To confirm this, Ikama Youth (2009) brings out a mission statement as to:

...provide disadvantaged secondary school leavers with the necessary skills and information, both academic and personal, to enable them to access the post school educational or employment opportunities for their choice. In addition, it works to offer young people from diverse backgrounds the opportunity to participate in the transportation of their communities. In achieving this mission, Ikama Youth aims to redress the persisting educational and economic inequalities in South Africa (p.4).

Such mission statements as the above can improve the economic and life status of the young people in particular, and the adults in general. Thus, the people do not depend on government employment. The secondary education curriculum in Nigeria is insufficient in the provision of necessary skills for improvement of' productivity in the economy or the country. It also lacks vocational training which can improve the economy of the country and make the individuals self-reliance. To illustrate the social and economic functions of secondary education and training, it can be seen in figure 2 as presented. 
Fig. 2: The Importance of Youth Development and Training

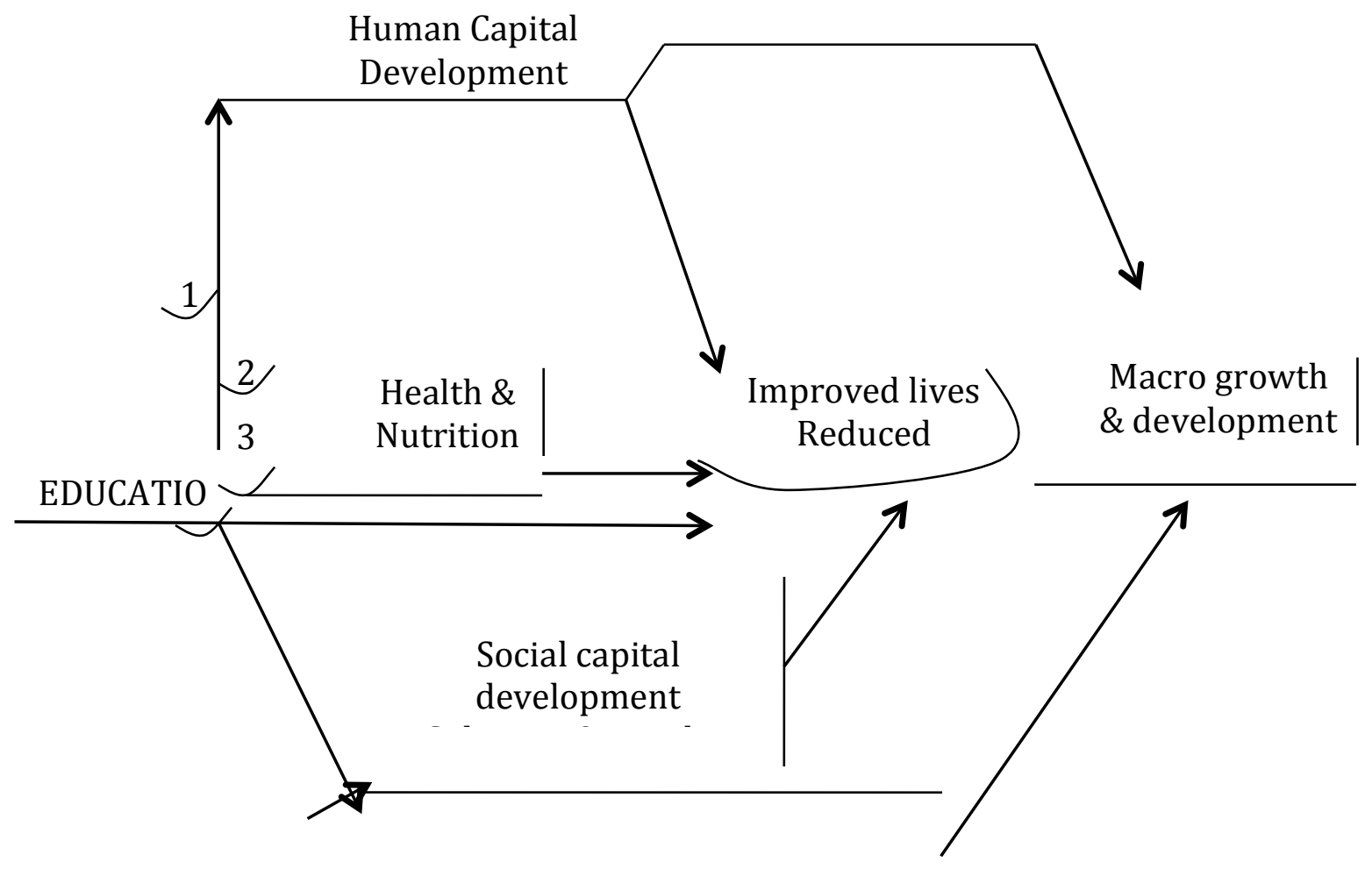

Adapted from World Bank (1999)

\section{Reading Comprehension}

Reading is focusing on comprehension and information gathering. The information gathered from the materials may be lessons or a lesson through an interaction or interactions with the writer. The information may be interview or instructive about how or processes of making a thing is learned. The lesson may also be giving of directives on where to go. Hence, functional literacy is the life-wire of human beings. To survive in this present world, one must have the ability to read and comprehend basic texts that are relevant to human existence. With the ability of comprehending what is read, people obviously are able to live safely and productively, and to also continue to develop socially, emotionally and intellectually Pearson (2013).

In simple terms, reading comprehension is an act of understanding what is read. It is an interactive process which takes place during reading a particular piece of a passage. The act of interaction is between the reader and the writer through the use of words, phrases, sentences and paragraphs and how these trigger the reader's knowledge outside the text. It is therefore imperative to know the importance of comprehension: without reading, comprehension becomes tracking of symbols on a page with eyes and sounding them out. Wikipedia (2015).

\section{The Question - Answer Relationship (QAR)}

Learners' reading comprehension ability can be measured at different levels. The first and the most common level is the literal understanding. Learners read at a literal level to find out some specific information (Cunningham \& Allington as cited in Farris. Fuhler\& Walther. 2004). Thus, a teacher can set questions on a passage that presents skills to be acquired in performing craft; for example, on knitting or on fashion designing. The answers to these questions should be at the literal level. 


\section{Inferential Comprehension}

When learners read at the level of understanding; they look for answers to inferential questions. This level moves the learners to higher level of comprehension. Learners make an inference to what is related to the reading material at hand. In this sense their reading focus goes beyond the mere words that are seen on the page "to reading between the lines" Farris, Fuhler \& Walter, (2004). Similarly, teachers should set questions on skills to be acquired for performing a craft.

For examples, the skills for making a basket or skills for producing fruit juice. The answers to these questions should be inferential.

\section{Critical Comprehension}

This type of comprehension is meant to keep the learners' thinking skimming over the surface of the text. The questions at the level are referred to as authentic questions which are behind quality learning. These questions are used as instruments to attain higher levels of comprehension-bearing some investigation.

\section{Reading Comprehension in ICTs}

Teachers of the English Language of different schools and classes should have collaborative teaching in reading comprehension in ICTs. This collaboration should be through publication of reading materials in CD-ROMS. These materials should be posted to internet, website for wider readers of different schools. For example, teachers should post reading materials on the following:

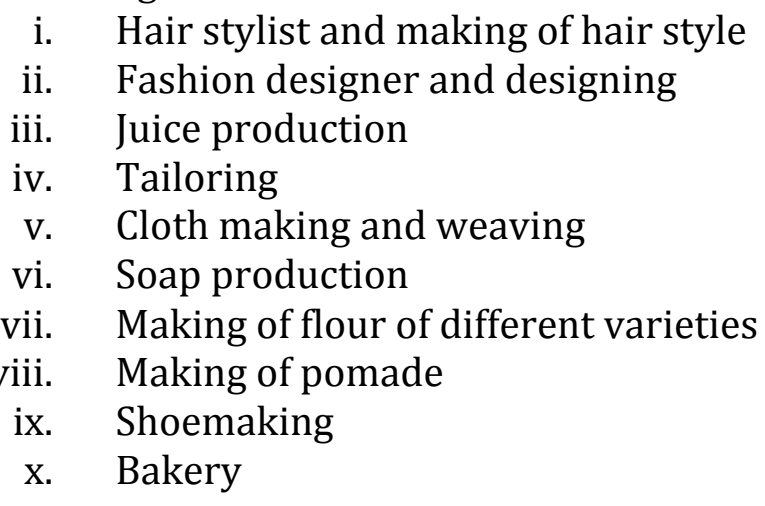

Each reading materials on the above should include steps and processes of making a particular product. The published materials in the CD-ROMs should be based on four levels of education: elementary learners (primary schools), middle learners (Basic education), high school (senior secondary school) students and students of higher institutions of learning (Brown, 2000). The reading materials in the CD-ROMs should also include skills to be acquired by the students who need to succeed in life. These skills will include career skills which help students to design a business plan for new business (Brown, 2000).

Teachers therefore give reading materials with assignment to students. The assignments should be on how to make or produce a particular product which is read about. Thus, the reading materials should always be accompanied with questions to be answered in note-books. These questions should be at the literal, inferential and critical levels of comprehension. In some cases, teachers give project assignments to students to do in pairs or in groups. Such assignments and projects can be on production of fruit-juice, fashion designing, shoemaking and many others. 
All activities: reading, answering of questions, group assignments and projects as done by the students are aimed at leading students to acquire skills for self-reliance.

\section{CONCLUSION}

The yearning of Nigerians then and now is to have the type of education that can make school graduate be self-dependent. To achieve this, the school curriculum must include classroom instruction that provides learners with opportunities to learn practical skills for self-reliance. It further implies that the curriculum should also include the use of ICTs for the purpose of learning and skills acquisition, learning becomes more meaningful if reading comprehension is used as a strategy for skill acquisition through the use of ICTs. Teachers of English Language must teach learners the strategies of reading comprehension.

\section{RECOMMENDATIONS}

The paper has suggested the following recommendations to concretise the discussion.

1. The school curriculum at all levels of education in Nigeria should include subject such as entrepreneurship and skills acquisition for self-reliance.

2. Information and Communication Technologies should be included in school curriculum at all levels of education in Nigeria.

3. Teachers of the English Language should always engage learners in reading comprehension in ICTs for skills acquisition.

4. Teachers of the English Language should always collaborate in the teaching of reading comprehension in ICTs.

5. Teachers should always give learners project assignments to produce some products they have reading about in internet, computer, twitter and others.

\section{References}

Brown, C. (2000). Curriculum for entrepreneurship education: A Review CELCEE Digest report number CELECEE; 00-8.

Brown, C. (2000). The consortium for entrepreneurship education, at fifth Ave. 99 Columbus, Ohio, 43-212. http://www.entre-ed.org/curriculum.

Bukola, A.H. (2011). Entrepreneurship education: An imperative for sustainable development in Nigeria, in Journal of emerging trends in Educational Research and Policy Studies (JETERAPS) 2(1,53-66).

Evoh, C.J. (2013). The role of social entrepreneurs in deploying ICTs for youth and community development in South Africa. A research report conducted Milano School of public and urban policy. The New School University, New York.

Farris, P.J. Fuhler, C.J. \& Walther, M.P. (2004). Teaching reading: A balanced approach for today's classrooms. New York: McGraw Hill.

Fife, E. \& Hosman, L. (2007). Public private partnership and the prospects for sustainable ICT projects in the developing world: in the Journal of Business System, Government and ethics. Vol.2 No.3, (pp.53-66)

Gusau, B.V. (2008). Educational reforms in Nigeria: Successive years of inconsistencies and confusions". A paper presented at Gusau Educational Development Association (GEDA), Interactive session. Retrieved from http://www.geda. One 15th of May, 2016.

Ikamva Youth (2009). 2008 Ikamva Youth Annual Report. Retrieved on 20th of March 2013. From http://www_ikamvayouth/files/active/ol/ yannual/Report2008.pdf.

Knowless, J.C. \& Behrman, J.R. (2006). "Assessing the economic returns to investing in youth in developing countries". In C.B., Lloyd. The Changing translation to adulthood in developing countries: selected studies. Washington D.C. The National Academics.

Lewis, T. (1999). Researching technology education-some areas of need". The Journal of Technology Education. Vol.10 number 2. Retrieved on March 25, 2013 from http://scholar.lib.vt.edu/ejournal/JTE/Vion2/lewis.html. 
Rinji, D.N., \& Ohaire, U. M. F. (2017). Infusing Skills Acquisition Contents In Reading Comprehension Via Information And Communication Technologies (Icts) For Economic Empowerment In Nigeria. Advances in Social Sciences Research Journal, 4(5) 124-132

Nwana, O.C. (2012). "Colonial and Neo-colonial Masters and their servants: Correlates of their educational policies and practices". A Keynote paper presented at the $3^{\text {rd }}$ annual Diamond International Education Conference on $23^{\text {rd }}$ of October 2012 at the International Conference Centre, Abuja.

Obanya, P. (1998), Patterns of educational reforms in Africa. Prospects, 28/4, 619-628. 